\title{
Nursing cares quality in nurses
}

\author{
Sore Khaki ${ }^{1 *}$, Simin Esmaeilpourzanjani ${ }^{2}$, Soheila Mashouf ${ }^{\mathbf{3}}$ \\ 1- Instructor, Department of Medical-Surgical Nursing, School of Nursing and Midwifery, Shahid Behishty \\ University, Tehran, Iran. (Corresponding Author), Tel: +989212468137 Email: skhaki170@gmail.com \\ 2- Instructor, Department of Community Health Nursing, School of Nursing and Midwifery, Islamic Azad \\ University, Tehran Medical Branch, Tehran, Iran. \\ 3- Instructor, Department of Medical-Surgical Nursing, School of Nursing and Midwifery, Islamic Azad \\ University, Tehran Medical Branch, Tehran, Iran.
}

Received: 6 July 2018

Accepted: 13 Aug 2018

\begin{abstract}
Background \& Aim: Quality is the most important index in healthcare services, especially nursing care. Since absolute quality cannot be achieved, it is crucial to assess this index on a regular basis. The present study aimed to evaluate the quality of nursing care services in nursing staff.

Materials \& Methods: This descriptive-analytical study was conducted on 210 nurses at Shahid Beheshti University in Tehran, Iran. The participants were selected via convenience sampling. Data were collected using a two-part demographic questionnaire and standard questionnaire of the quality of care by Koval and Peck with 72 items in the psychosocial, physical, and interactive dimensions. Data analysis was performed in SPSS version 16 using descriptive and inferential statistics.

Results: Mean age of the nurses was 33.53 years. Among the participants, 20\% were male, and $76.1 \%$ were female. Quality of nursing care was considered favorable in the psychosocial $(84 \%)$, physical $(79 \%)$, and interactive dimensions (68.5\%). Moreover, the results of MannWhitney $U$ test indicated a significant association between the quality of nursing care and gender, so that female nurses provided better care compared to male nurses $(\mathrm{P}=0.01)$.

Conclusion: In the viewpoint of the nurses, the quality of nursing care was favorable. Nevertheless, the expectations of patients are not met in some cases. Therefore, it is recommended that the standards of the quality of care be re-evaluated in terms of the structure, processes, and outcomes from the perspective of nurses and patients in order to adopt effective strategies to enhance proper healthcare interactions between nurses and patients and meet the psychosocial needs of patients as far as possible.
\end{abstract}

Keywords: Quality of Care, Nurses, Nursing

How to cite this article:

khaki S, Esmaeilpourzanjani S, Mashouf S. Nursing cares quality in nurses . Scientific Journal of Nursing, Midwifery and Paramedical Faculty. 2018; 3 (4) :1-14

URL: http://sjnmp.muk.ac.ir/article-1-139-a.html

Copyright $\odot 2018$ the Author (s). Published by Kurdistan University of Medical Sciences. This is an open access article distributed under the terms of the Creative Commons Attribution-Non Commercial License 4.0 (CCBY-NC), where it is permissible to download, share, remix, transform, and buildup the work provided it is properly cited. The work cannot be used commercially without permission from the journal. 


\title{
كيفيت مراقبتهاى يرستارى در يرستاران
}

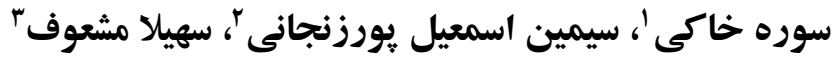

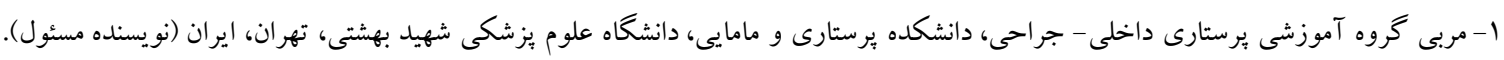 \\ ايميل: skhaki170@gmail.com

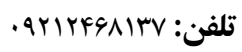

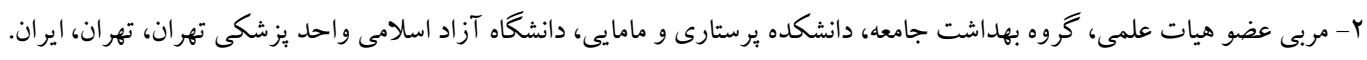

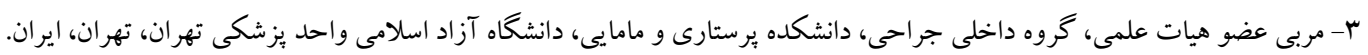

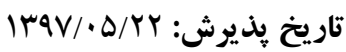

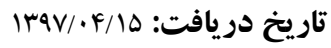

جكيده زمينه و هدف: كيفيت مهم ترين مسئله در عرصه خدمات سلامت بهويزٔه مراقبت برستارى است از آنجايى كه هر گز نمى توان به

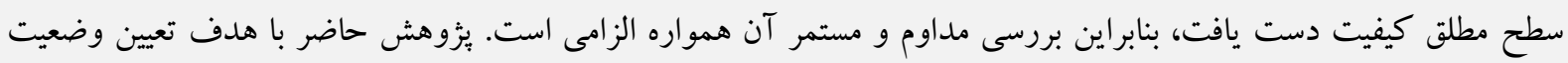

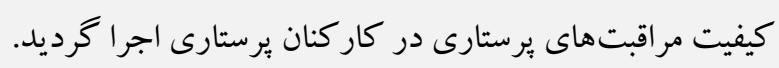

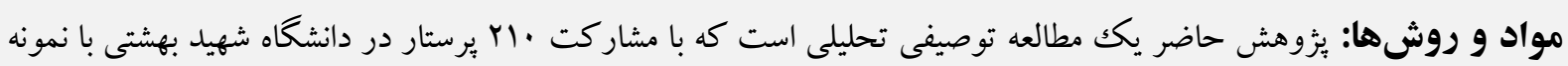

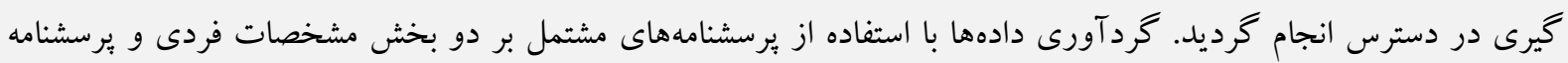

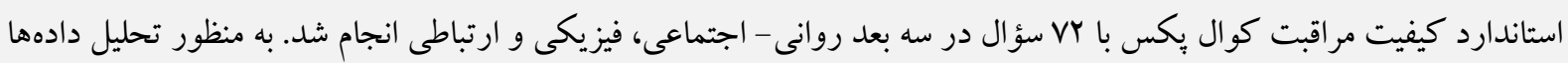

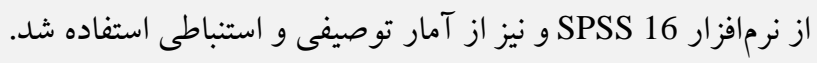

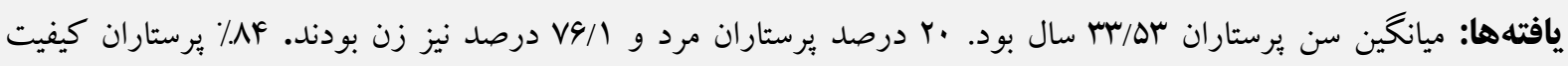

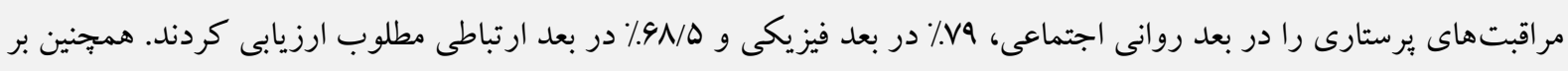

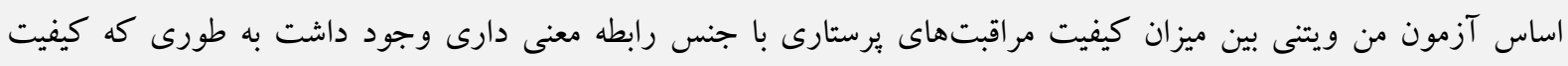

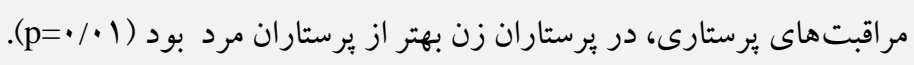

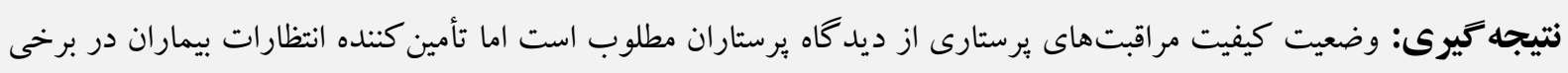

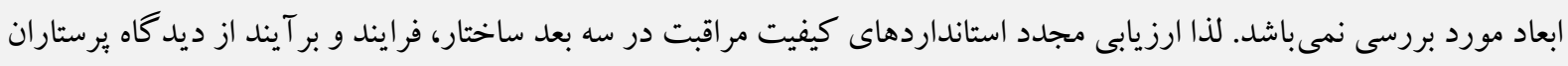

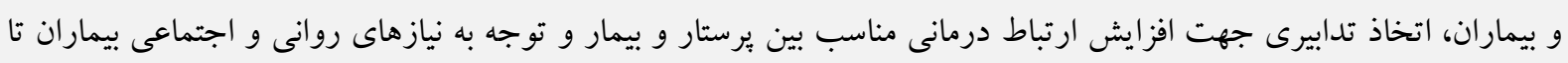
حد امكان مى تواند سودمند واقع شود. وازههاى كليدى: كيفيت مراقبت، يرستاران، بِرستارى

مطرح شده و به تدريج دامنه رسوخ اين نهضت از مقدمه

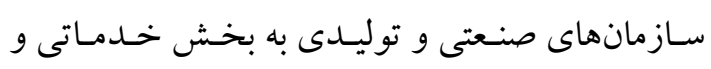
كيفيت رويكردى است كه در جند دههى اخير در

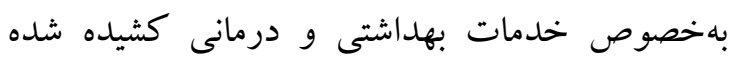
بخش صنعت براى بهبود دائمى فر آيندها كه در نهايت

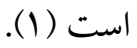
منجر به توليدات مرغوب و مورد نياز مشتريان مىشود، 
جسمى، روانى و اجتماعى مىشود (·))؛ بنابراين با توجه به افزايش هزينههاى خدمات بهداشتى و درمانى، ارتقاى مداوم كيفيت خدمات برستارى امرى است لازم و كنترل كيفيت خدمات يرستارى جهت افزايش رضايت مشتريان هم ضرورت دارد (1))؛ به عبارت ديخر، كيفيت، توانايى يك فر آورده يا خدمت براى ارضاء نيازهاى ابراز شده و ميزانى براى برآوردن انتظارات مشترى يا مددجو است (r).

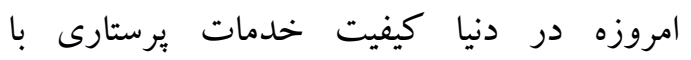
جالشهاى فراوانى روبرو است. مطالعهاى كه در

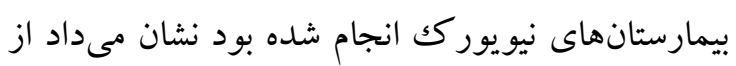

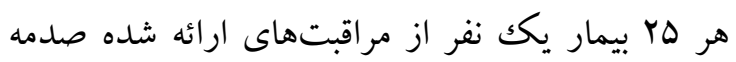

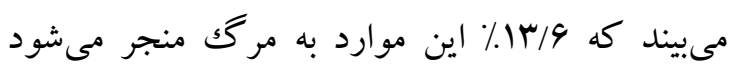
(Y) (I). اين در حالى است كه اغلب مددجويان و بيماران به علت افزايش سطح آكاهى در زمينه بهداشت و درمان و نيز افزايش هزينه خدمات بهداشتى، خواستار خدمات باكيفيت مطلوب هستند (rا). از طرفى نيز

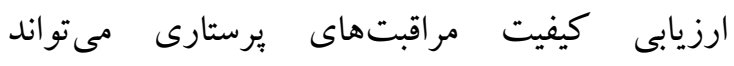
اصلاحاتى در نحوه خدمترسانى به وجود آورد تا خدمات طبق الكوهاى استاندارد سلامتى اجرا شود. امروزه توسعه روزافزون كيفيت گرايى در بخش درمان و لزوم رعايت استانداردها به صورت موضوعى قابل تحقيق مطرح شده است. تحقيقات انجام شده در اين زمينه نيز نشان مىدهد ارزيابى كيفيت مراقبتها باعث

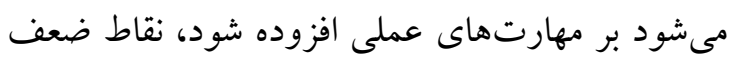
مشخص شود، خدمات با دقت بيشتر اجرا شود، اشكالات موجود در بخشها و نارضايتىها برطرف

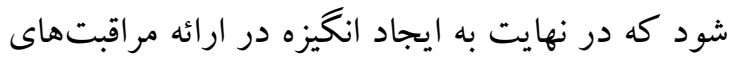
باكيفيت بالاتر و برآوردن خواسته و نياز بيماران

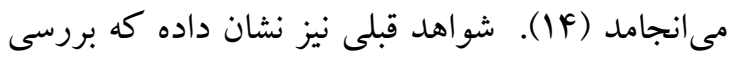

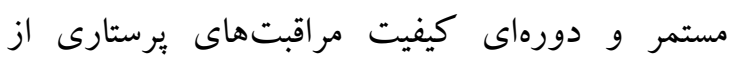

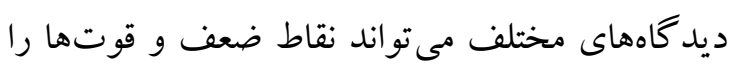

با كذر زمان نيز نياز بيماران، خانواده آنها، شركتهاى بيمه و متخصصان بهداشت و درمان به ارتقاى كيفيت در زمينه مراقبت از بيماران فزونى يافته است (Y). به طورى كه در سازمانهاى رقابتى امروز، فقط سازمانهايى قادر به ادامه حيات هستند كه كاراى و كيفيت خدمات خود را ارتقاء دهند (r). كيفيت خدمات سلامت به معناى دستيابى به مطلوبترين بر آيندهاى سلامتى است (F)؛ به كونهاى كه خدمات ارائه شده اثربخش، كارا و بهصرفه باشد

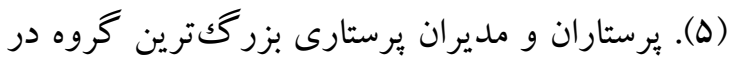

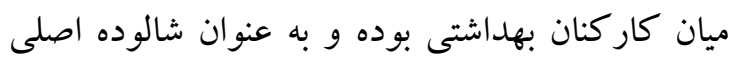
فرايند بهبود كيفيت مراقبتها هستند، بنابراين عملكرد آنها در بيشبرد اهداف سازمانى بسيار مثمر ثمر است (9). توانمندى حرفهاى آنها نقش مهمى در تحقق رسالت نظام سلامت ايفا مى كند. به همين دليل ميزان توانمندى حرفهاى و كيفيت مراقبتى آنها يكى از دغدغههاى نظامهاى بهداشتى و متوليان سلامت در كشورهاى مختلف است (V). وبرستاران از ديد قانونى و اخلاقى بايد پِاسخگُى كيفيت مراقبتهاى ارائه شده باشند. مطالعات نشان دادهاند كه افزايش هزينههاى مراقبت، كاهش تعداد برستاران حرفهاى و به كارگيرى برستاران دوره نديده يا ساير كاركنان

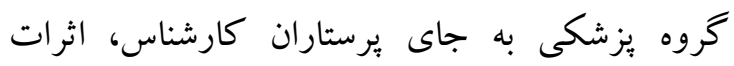

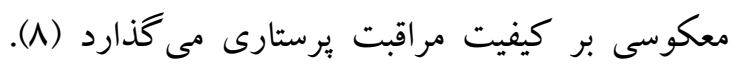
امروزه به دليل تأكيد فراوان روى مديرت منابع، كنترل هزينه، اثربخشى مراقبت از بيمار، ارتقاء كيفيت و مسئوليت يذيرى، مراقبت خوب از بيمار امرى ضرورى است (9). حتى برخى معتقدند كيفيت مراقبت مرابيت

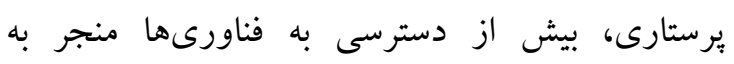

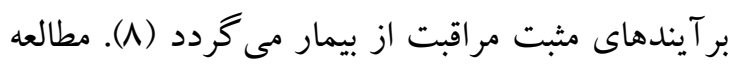
نشان داد كه از ديد بيمار ارائه مراقبت Williams يرستارى باكيفيت موجب دستيابى به مراقبتهاى 
مراقبتهاى برستارى و شناسايى عوامل مرتبط با آن در كار كنان برستارى انجام گرديد.

مواد و روشها

اين بثزوهش يكك مطالعه توصيفى تحليلى است كه با هدف تعيين وضعيت كيفيت مراقبتهاى برستارى و ارتباط آن با متغيرهاى جمعيت شناختى در كاركنان

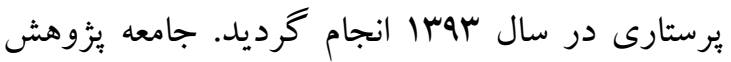
شامل برستاران شاغل در ه بيمارستان منتخب دانشگًاه علوم بز شكى شهيد بهشتى شهر تهران بود. بدين ترتيب ابتدا فهرست تمامى بيمارستانهاى آموزشى و درمانى كه زير مجموعه دانشگاه علوم يزشكى شهيد بهشتى بودند تهيه و سبس با بهره گيرى از روش نمونه گيرى تصادفى ساده، ه مركز شهداى تجريش، لبافى نزاد، امام حسين (ع)، مدرس و مهديه انتخاب و از همه بخشهاى بيمارستانهاى منتخب بهجز بخش اطفال با استفاده از

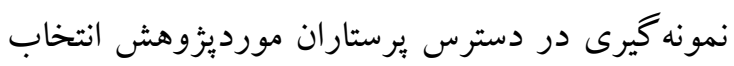
كرديد. معيارهاى ورود به مطالعه براى برستاران شامل: تمايل به شركت در بثزوهش، داراى تحصيلات فوقدييلم و بالاتر در رشته يرستارى و حداقل 9 ماه Mابقه كار بود. تعداد نمونهاى بزوهش نيز شامل . يرستار شاغل در مراكز آموزشى و درمانى بيمارستانهاى نامبرده بودند كه با توجه به مطالعه

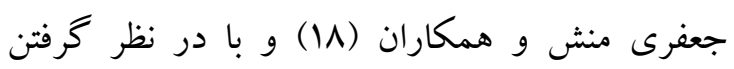

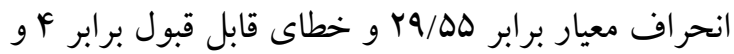
سطح اطمينان 9ه٪ و با استفاده از فرمول حجم نمونه تعيين شد. ابزار جمع آورى اطلاعات در اين بثوهش بش بـ شامل برسشنامه اطلاعات فردى شامل سن، جنس، وضعيت تأهل، مدر كك برستارى، وضعيت استخدامى، نوبت كارى و سابقه خدمتى و برسشنامه استاندارد Quality patient care scale بريت مراقبت بود. اين يرسشنامه شامل VY سؤ ال بود (QUALPAC) كه وضعيت كيفيت مراقبتهاى برستارى را در سه بعد بر برس
مشخص نموده و در طراحى برنامهاى مطلوب براى ارتقاى كيفيت خدمات مثمر ثمر واقع گردد. در مطالعه نيشابورى و همكاران، نتايج نشان داد

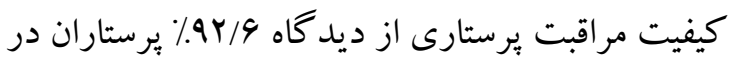
بعد روانى اجتماعى و ه9/1٪ در بعد ارتباطى مطلوب

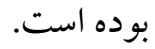
از ديدگاه 9/اس/٪ بيماران كيفيت مراقبت برستارى در بعد روانى اجتماعى و YF/V٪ در بعد ارتباطى مطلوب

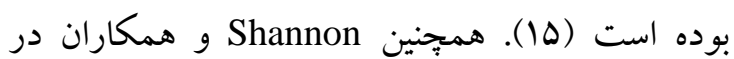

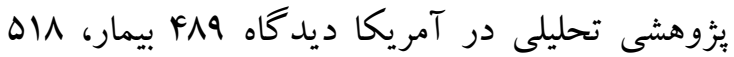
برستار و هاه بز شكك را در خصوص كيفيت مراقيت مقايسه نمودند كه يافتها نشان داد ميانخين كيفيت

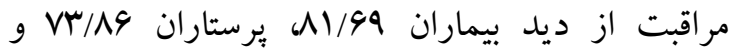

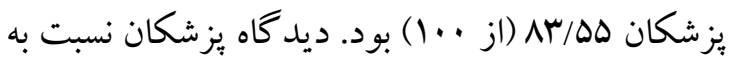
يرستاران و بيماران بالاتر بود در حالى كه يرستاران

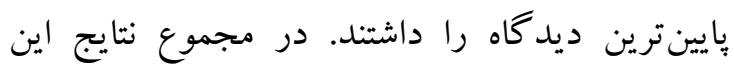
بزوهش حاكى از تفاوت ديد گاه برستاران، يزشكان و بيماران از كيفيت مراقبت برستارى بود (19). بنابراين با توجه به نتايج بهدست آمده مبنى بر نامطلوب بودن كيفيت مراقبتهاى يرستارى از ديد بيماران و وجود تفاوت بين ديدكاه يرستاران و بيماران در اين خصوص (ها، (، IV)، انجام اقداماتى در اين زمينه ضرورى به نظر مىرسد؛ بنابراين جهت نيل به اين هدف، ارزيابى مجدد استانداردهاى كيفيت مراقبت

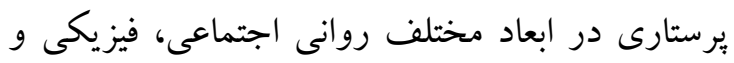

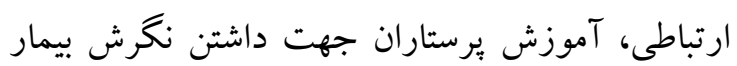
محورى در زمينه ارائه خدمات بِرستارى، ارتقا تخصص حرفهاى، اتخاذ تدابيرى جهت افزايش ارتباط درمانى مناسب بين برستار و بيمار و توجه به نيازهاى روانى و

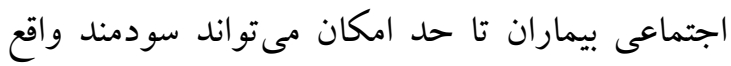
شود. لذا مطالعه حاضر با هدف تعيين وضعيت كيفيت 
يُزوهشخ با مجوز از معاونت بثزوهشى دانشگاه آزاد اسلامى واحد علوم بزشكى تهران و موافقت مسئولين بيمارستانها به محيط يُزوهش وارد شد. سبس با تكميل رضايتنامه كتبى و آكاهانه توسط يُرستاران به آنها

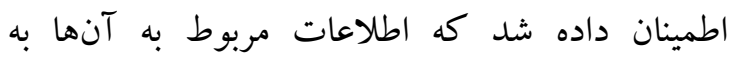
صورت كاملاً محرمانه و بدون نام مورد بررسى قرار خواهد گرفت و در نهايت به صورت كلى (نه موردى) كزارش خواهد شد و به مسئولين بيمارستانها نيز در

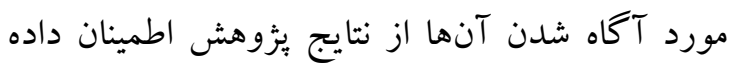
شد. اطلاعات بهدست آمده با استفاده از نرمافزار كPS

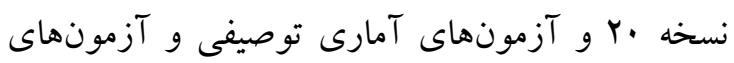

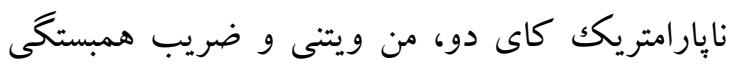

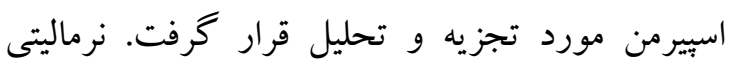
دادهها از طريق آزمون كولمو گروف اسميرنف انجام

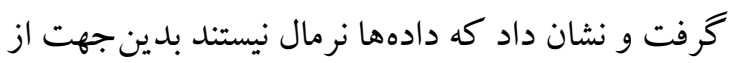
آزمونهاى نايارامتريك استفاده گرديد. جهت تحليل دادهها نيز سطح معنىدارى آمارى هـ/ • در نظر گرفته

\section{يافتهها}

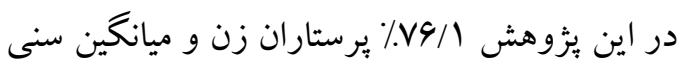
آنها F

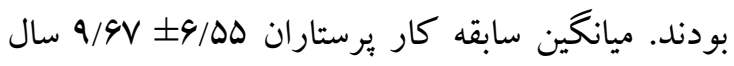
بود. ساير مشخصات نيز در جدول شماره يكك آمده است (جدول شماره ()).
روانى - اجتماعى (سM سؤال)، بعد فيزيكى (4 سؤال) و بعد ارتباطى (سا سؤ ال) بررسى مىنمود.

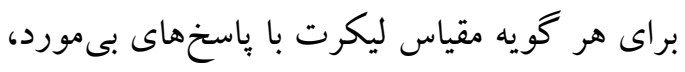

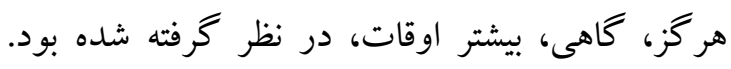
توزيع نمرات كيفيت مراقبت يرستارى نيز به صورت

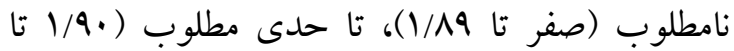

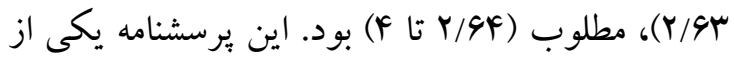
معتبرترين ابزارهاى اندازهگيرى كيفيت مراقبت مىباشد

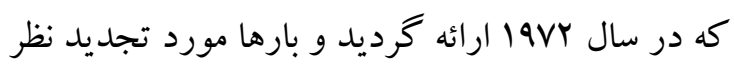

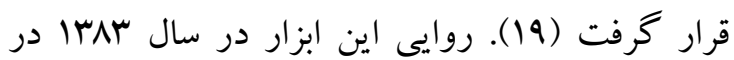
تبريز توسط خوشخو مورد بررسى و با فرهنگ ايران

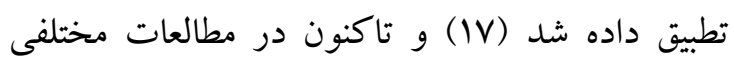
روايى آن مورد تائيد و به كار گرفته شده است (هال

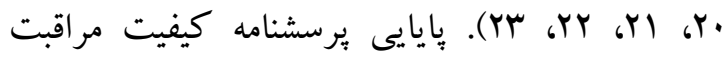
نيز در مطالعات متعددى مورد تائيد قرار QUALPAC كرفته است (ها، VIا، YI) برسشنامه كيفيت مراقبت با اندازه گيرى ضريب آلفاى

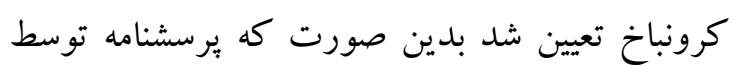
ت r.

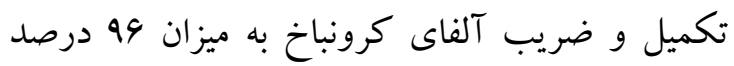
محاسبه و مورد تائيد قرار كرفت.

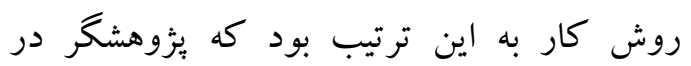
روزهاى مختلف هفته و در شيفتهاى متفاوت صبح،

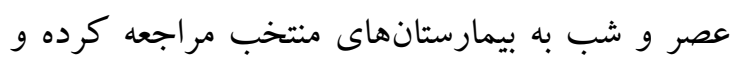
اقدام به جمع آورى اطلاعات نموده و در همان روز يرسشنامهها را جمع آورى كرده است.

\begin{tabular}{|c|c|c|c|}
\hline درصد & تعداد & \multicolumn{2}{|c|}{ متغير جمعيت شناختى } \\
\hline$\vee q / 1$ & 109 & 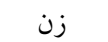 & \\
\hline r. & (1) & 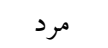 & جنسيت \\
\hline$r / 9$ & $\wedge$ & بى ياسخ & \\
\hline 94 & IYF & سراسرى & دانشگاه محل اخذ مدر كى \\
\hline
\end{tabular}




\begin{tabular}{|c|c|c|c|}
\hline$M T / \Delta$ & 90 & آزاد & \\
\hline$\Delta / \Delta$ & 11 & بى ياسخ & \\
\hline$\Delta$ & 1. & فوق دييلم & \multirow{4}{*}{ مدرك بِرستارى } \\
\hline$\Delta F / \Delta$ & 199 & كارشناسى & \\
\hline$\wedge$ & 19 & كارشناسى ارشد & \\
\hline$r / \Delta$ & $\Delta$ & بى پياسخ & \\
\hline $10 / 0$ & m & ثابت & \multirow{3}{*}{ نوبت كارى } \\
\hline$\Lambda r / \Delta$ & 190 & درگردش & \\
\hline$r$ & f & بى باسخ & \\
\hline if & rı & طرحى & \multirow{5}{*}{ وضعيت استخدام } \\
\hline$r / \Delta$ & kr & قراردادى & \\
\hline$r 9 / 0$ & $\Delta r$ & رسمى آزمايشى & \\
\hline rv & $v^{f}$ & رسمى قطعى & \\
\hline 1 & r & بى ياسخ & \\
\hline
\end{tabular}

و علائم روانى قادر به تشخيص اضطراب بيمار هستند. ه/9/1\% يرستاران از معرفى بيمار جديد به بيمار اجتناب مى كنند، ه/N.٪ هر گز به تقاضاى بيمار براى ديدن يك روحانى توجه نمى كنند و ه/ه/ نيز بيمار را از زمان ورود و خروج خود مطلع نمى كنند (جدول شماره Y).
يافتهها در خصوص وضعيت كيفيت مراقبتهاى يرستارى در بعد روانى اجتماعى نشان داد كه ه/9r\% از برستاران بيان كردهاند كه به سخنان بيماران توجه مى كنند و كلامشان را قطع نمى كنند. /1/ / \% بيان كردند با حوصله و مهربانى به سؤالات بيماران ياسخ مىدهند و 91\% نيز اظهار داشتند از روى علائم فيزيكى

جدول r: توزيع ميانكين كيفيت مراقبتهاى ثرستارى در بعد روانى - اجتماعى از ديدكاه يرستاران

\begin{tabular}{|c|c|c|c|c|}
\hline \multicolumn{4}{|c|}{ بر بتار } & \multirow{2}{*}{ سؤ الات كيفيت مر اقبتهاى برستارى در بعد روانى - اجتماعى } \\
\hline 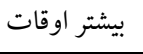 & كاهى & هركز & 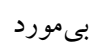 & \\
\hline $91 / \Delta$ & $\mathrm{V} / \Delta$ & 1 & · & 1. ياسخ دادن با حوصله و مهربانى به سؤالات بيمار \\
\hline$V * / \Delta$ & rr & $1 / \Delta$ & 1 & r. فراهم كردن محيط مناسبى جهت پِاسخ دادن به سؤالات بيمار \\
\hline vo & $r Y / \Delta$ & $r / \Delta$ & $\cdot$ & r. صحبت با همكاران فقط در رابطه با بر آورده كردن نيازهاى بيماران \\
\hline$\wedge \cdot$ & $10 / 0$ & $r / \Delta$ & 1 & f. لحن صداى برستاران نشاندهنده علاقه آنها جهت رفع مشكلات و نيازهاى بيمار \\
\hline $9 Y / \Delta$ & 4 & $1 / \Delta$ & · & ه. توجه كردن يرستاران به سخنان بيمار \\
\hline M & $9 / \Delta$ & 1 & $1 / 0$ & 9. احساس رضايت پس از گفتخو با يرستاران \\
\hline$\Lambda r / \Delta$ & if & $r / \Delta$ & $\cdot$ & V. Vدازدن بيمار با نام نه با شماره تخت \\
\hline$v F$ & $r r / \Delta$ & $r / \Delta$ & . & 1 1 معرفى كردن برستاران به بيمار \\
\hline$\wedge 1$ & IV/D & 1 & $\cdot / \Delta$ & 9. برخورد منطقى يرستاران با بيمار در صورت بروز رفتار نامناسب \\
\hline$\Delta q$ & $r F / \Delta$ & $r / \Delta$ & r & •. صرف زمان بيشتر يرستاران در موقع احساس تنهايى بيمار \\
\hline$\wedge 9$ & ir & 1 & 1 & 11. صحبت با بيمار در صورت خسته شدن از درمان و تشويق به ادامه درمان \\
\hline $9 \cdot / \Delta$ & $V / \Delta$ & $\cdot / \Delta$ & $1 / 0$ & r ا. خوددارى يرستار از عصبانى شدن يا به زبان آوردن كلمات نإسند در برخورد با بيمار \\
\hline 91 & $9 / 0$ & $\cdot / \Delta$ & r & rا. توانايى برستاران در تشخيص و كاهش اضطراب بيمار \\
\hline
\end{tabular}




\begin{tabular}{|c|c|c|c|c|}
\hline$\Lambda r / \Delta$ & $\mid f / \Delta$ & $1 / 0$ & $1 / 0$ & 1F. ماندن در كنار بيمار در صورت احساس اضطراب و سعى در كاهش آن \\
\hline$\Lambda F$ & If & $1 / 0$ & $\cdot / \Delta$ & اله اجازه دادن به ماندن يكى از خانواده بيمار در كنار وى در صورت كاهش نيافنن \\
\hline$\Lambda V / \Delta$ & $11 / 0$ & $\cdot 10$ & $\cdot / 0$ & 19. توضيح دان مجدد با روى خوش و بدون اظهار ناراحتى براى بيمار \\
\hline$\vee 9 / \Delta$ & r. & $\cdot$ & $\cdot / \Delta$ & IV. توضيح دادن انجام مر اقبتهاى درمانى و آزمايشها براى بيمار \\
\hline$\wedge$ & 10 & 1 & 1 & 11. قرار دادن بيمار در جريان روند بهبودى خود \\
\hline$\Delta \wedge$ & $\mu r / \Delta$ & $\mathrm{V} / \mathrm{\Delta}$ & r & 19. مطلع كردن بيمار از زمان ورود و خروج يرستار \\
\hline$\wedge q$ & $11 / 0$ & $\cdot / 10$ & r & •r. انجام اقدامات درمانى در كمترين تداخل با زمان ملاقات \\
\hline$V \wedge / \Delta$ & r. & $r / \Delta$ & 1 & Ir. فراهم كردن محيطى مناسب جهت برقرارى ارتباط بيمار با خانو ادهاش \\
\hline fo & $m / \Delta$ & $\Lambda / \Delta$ & 10 & rr. توجه به تقاضاى بيمار براى ديدن يكك روحانى \\
\hline $9 r / \Delta$ & $r V / \Delta$ & $r / \Delta$ & $9 / 0$ & سا. آموزش به بيمار جهت انجام فرايض دينى با توجه به شرايط جسمى \\
\hline$M / \Delta$ & $9 / \Delta$ & $1 / 0$ & $\cdot / \Delta$ & TF باسخ با حوصله به سؤالات بيمار در رابطه با بيمارى خود \\
\hline$\wedge r / \Delta$ & $10 / \Delta$ & r & $\cdot$ & ها. حكمفرما بودن محيطى حاكى از اعتماد بين بيمار و يرستاران \\
\hline $11 / \Delta$ & 19 & 1 & $1 / 0$ & به ب. توجه كردن به نظرات بيمار در رابطه با مر اقبتهاى انجام شده و در صورت امكان اعمال \\
\hline 94 & r & r & 1 & VV صحبت كردن در مورد موضوعات مورد علاقه بيمار در حين مراقبت \\
\hline$M F / \Delta$ & f. & $19 / 0$ & 4 & 1Y. معرفى كردن بيمار جديد به بيماران ديخر \\
\hline $\mathrm{V} / \mathrm{Q}$ & 11 & $r / \Delta$ & 1 & qج. توضيح دادن علت رعايت برخى از قوانين بخش براى بيمار \\
\hline$\Delta V / \Delta$ & $r \Delta / \Delta$ & $\Delta / \Delta$ & $1 / 0$ & •r. آشنا كردن بيمار با بيماران داراى مشكلات مشابه \\
\hline$\Delta 9 / \Delta$ & ro & f & $1 / \Delta$ & آس. آموزش انجام كارهاى شخصى به تنهايى با توجه به شرايط جسمى بيمار \\
\hline Vr & rF & r & 1 & rr. تشويق كردن خانو اده در امر مراقبت از بيمار \\
\hline
\end{tabular}

دادن دارو به بيمار حتماً نام وى را سؤال مى كنند.

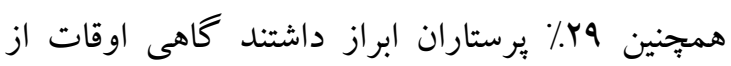
مواد معطر جهت خوشبو كردن محيط استفاده مى كند.

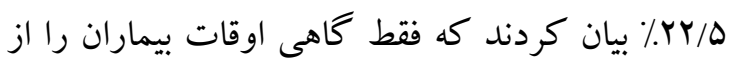

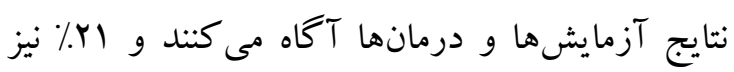
بيان كردند فقط كاهى اوقات استراحت متناوب در بين

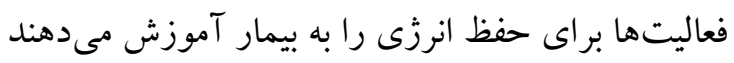

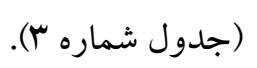

وضعيت كيفيت مراقبتهاى يرستارى در بعد

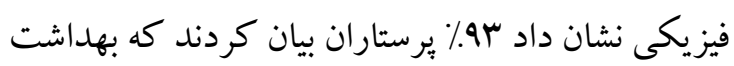

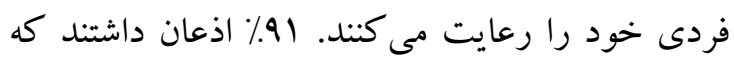

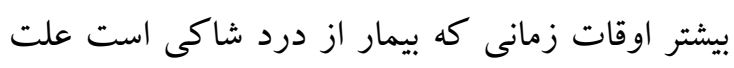

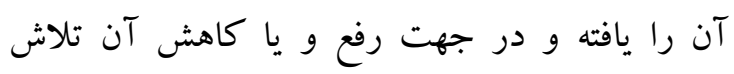

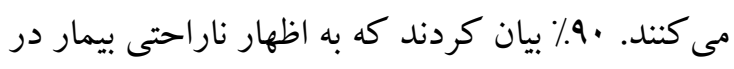

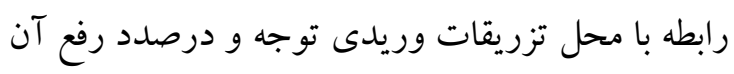

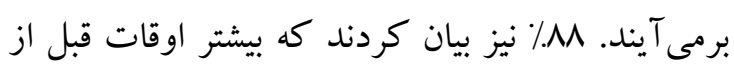

جدول بّ: توزيع ميانكين كيفيت مراقبتهاى ثرستارى در بعد فيزيكى از ديدكاه يرستاران

\begin{tabular}{|c|c|c|c|c|}
\hline \multicolumn{4}{|c|}{ برستار } & \multirow{2}{*}{ سؤالات كيفيت مراقبت هاى برستارى در بعد فيزيكى } \\
\hline 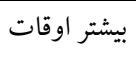 & كاهى & هرغز & 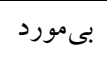 & \\
\hline vr & $r r / \Delta$ & $r / \Delta$ & . & سب. آكاه كردن از نتايج آزمايشها و درمانها \\
\hline Ar & 19 & $1 / 0$ & $\cdot / \Delta$ & FF \\
\hline 19 & $9 / \Delta$ & $\cdot / \Delta$ & 1 & هr. تنظيم كردن ميله كنار تخت و توضيح دادن در مورد آن \\
\hline va & $r \cdot / \Delta$ & $r / \Delta$ & 1 & 4.r. بر آورده كردن نيازهاى بهداشتى روزانه \\
\hline
\end{tabular}




\begin{tabular}{|c|c|c|c|c|}
\hline V4 & $r \cdot / \Delta$ & r & $\cdot / \Delta$ & TV. كمك كردن به بيمار براى انجام كارهاى شخصى در صورت ناتوانى \\
\hline$V N / \Delta$ & 19 & $1 / 0$ & 1 & میr. كنترل كردن روزانه بهداشت محيط \\
\hline$\Delta V / \Delta$ & rq & $1 \cdot$ & $r / \Delta$ & هץ. استفاده كردن مواد معطر جهت خوشبو كردن محيط \\
\hline$V N / \Delta$ & $1 / 10$ & r & 1 & • ع. حمايت روحى از بيماران \\
\hline$\wedge \Delta$ & $1 r / \Delta$ & . & $1 / \Delta$ & أF. انجام اقدامات مر اقبتى لازم با مهارت مناسب \\
\hline$\Lambda \Delta / \Delta$ & $1 r / \Delta$ & $\cdot / 0$ & $1 / 0$ & Fr.Fr. انجام دادن مراقبتهاى لازم جهت حفظ بهداشت يوست \\
\hline va & $10 / \Delta$ & $r / \Delta$ & r & سلز. توجه به تغييرات وزنى بيمار \\
\hline$\wedge \Delta$ & 11 & $r / \Delta$ & $\cdot / \Delta$ & FF FF. توجه به الكو غذايى بيمار \\
\hline$\Lambda 1 / \Delta$ & 10 & r & $\cdot / \Delta$ & هاF. توجه به الكو خو اب و استراحت بيمار \\
\hline$\Lambda r / \Delta$ & 19 & 1 & $\cdot / \Delta$ & 49. توجه به الكوى دفعى بيمار \\
\hline 91 & $V / \Delta$ & $\cdot / \Delta$ & 1 & FV \\
\hline 9. & $\wedge$ & $\cdot / \Delta$ & $1 / \Delta$ & آن أ. توجه به اظهار ناراحتى بيمار در رابطه با محل تزريقات وريدى و تلاش براى رفع \\
\hline$W / \Delta$ & 11 & r & $1 / \Delta$ & q4. توضيح دادن در خصوص انجام صحيح حر كات ورزشى در صورت نياز بيمار \\
\hline$\Delta F$ & $1 r / \Delta$ & $1 / 0$ & r & •ه. آموزش دادن در مورد انجام تنفس صحيح و تخليه ترشحات ريه و علت آن \\
\hline$\Lambda \cdot / \Delta$ & $10 / \Delta$ & $r / \Delta$ & $1 / \Delta$ & اه. كمكك كردن به بيمار در امر خروج از تخت و راه رفتن \\
\hline$V F$ & rI & $r / \Delta$ & $r / \Delta$ & rه. آموزش استراحت متناوب در بين فعاليتها براى حفظ انرزى \\
\hline$\Lambda r$ & if & 1 & $r$ & سه. آموزش علت خروج از تخت بعد از عمل \\
\hline$\Lambda \varepsilon / \Delta$ & Ir & . & $\cdot / \Delta$ & هf \\
\hline$\Lambda \Lambda$ & $11 / \Delta$ & $\cdot / \Delta$ & . & ههـ. سؤال كردن نام بيمار قبل از دادن دارو به وى \\
\hline$\wedge$. & $19 / 0$ & $\cdot / \Delta$ & . & هو. توضيح دادن در رابطه با اثرات درمانى داروى مصرفى \\
\hline $\mathrm{VQ} / \Delta$ & 19 & $1 / 0$ & · & هV توضيح دادن در رابطه با اثرات جانبى و هشدار دهنده دارو \\
\hline$\Lambda Y / \Delta$ & 10 & $1 / \Delta$ & 1 & هAه. سؤال كردن در رابطه با سابقه حساسيت بيمار به غذا يا دارو خاص \\
\hline ar & 9 & $\cdot / \Delta$ & $\cdot / \Delta$ & ه9. رعايت بهداشت فردى برستار \\
\hline
\end{tabular}

همجنين 19/ه٪ برستاران بيان كردند كه كاهى اوقات

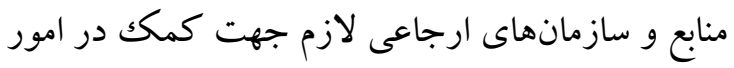

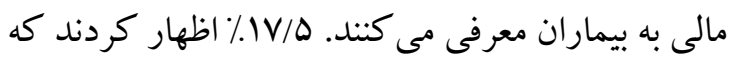
كاهى اوقات سعى مى كند نيازهاى بيماران را بيش بينى

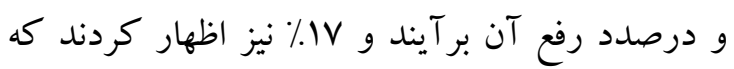

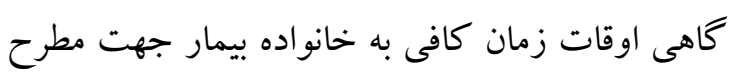
كردن سؤالات خود قرار مى دهند (جدول شماره F).
وضعيت كيفيت مراقبتهاى برستارى در بعد ارتباطى نيز نشان داد 91\% از يرستاران بيان كردند كهان بيشتر اوقات با ساير كار كنان درمانى بيمارستان ارتباط

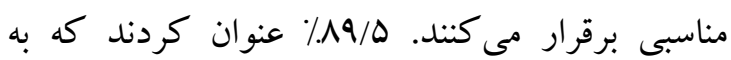

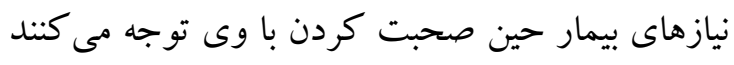
و ه9. نيز ابراز داشتند كه بيشتر اوقات احتياجات بيمار را در محيطى آرام و بدون اضطراب بر آورده مى كند.

\section{جدول ع: توزيع ميانكين كيفيت مراقبتهاى برستارى در بعد ارتباطى از ديد كاه يرستاران}

\begin{tabular}{|c|c|c|c|c|}
\hline \multicolumn{4}{|c|}{ يربرستار } & \multirow{2}{*}{ سؤالات كيفيت مر اقبتهاى برستارى در بعد ارتباطى } \\
\hline بيشتر اوقات & كاهى & هر خز & 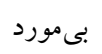 & \\
\hline Ar & $19 / 0$ & $\cdot / \Delta$ & 1 & •9. بهراحتى در ميان گذاشتن احساسات خود (بيمار) با برستاران \\
\hline$\Lambda \vee$ & $1 r / 0$ & $\cdot / \Delta$ & . & 91. بهراحتى برسيدن سؤالات در رابطه با بيمارى از برستاران \\
\hline
\end{tabular}




\begin{tabular}{|c|c|c|c|c|}
\hline$\wedge 9$ & $1 \cdot / 0$ & $\cdot$ & $\cdot / 0$ & r و و. به خوبى گوش دادن به سخنان بيمار \\
\hline$\wedge 1$ & IV & 1 & 1 & بو. در اختيار قرار دادن زمان كافى به خانواده بيمار جهت مطرح كردن سؤالات خود \\
\hline$\wedge 9$ & 1. & $\cdot / 0$ & $\cdot / 0$ & 44. احساس رضايت خانو اده از ياسخ برستاران \\
\hline$\Lambda \mathrm{V} / \mathrm{\Delta}$ & $11 / 0$ & $\cdot / \Delta$ & $\cdot / \Delta$ & 90. دركك اضطراب خانواده بيمار و دادن آموزشهاى لازم جهت كاهش اضطراب آنها \\
\hline$\Lambda r / \Delta$ & $1 F / \Delta$ & $1 / \Delta$ & $\cdot / \Delta$ & 94. قرار دادن خانو اده بيمار در جريان روند بهبودى بيمار \\
\hline$\Lambda \mathrm{V} / \mathrm{\Delta}$ & $11 / ه$ & 1 & $\cdot$ & 9V \\
\hline$\Lambda \cdot / \Delta$ & $\mathrm{IV} / \Delta$ & 1 & 1 & 91. يُش يينى برخى از نيازهاى بيمار حتى قبل از عنوان آن توسط بيمار \\
\hline 91 & v & 1 & 1 & 99. برقرار كردن ارتباط مناسب يرستاران با ساير كار كنان درمانى \\
\hline$V \wedge / \Delta$ & $19 / 0$ & r & . & •V. معرفى كردن منابع و سازمانهاى ارجاعى لازم به بيمار \\
\hline 19 & 1. & 1 & . & Vا. بر آورده كردن احتياجات بيمار در محيطى آرام و بدون اضطراب \\
\hline$\wedge 9 / \Delta$ & 9 & $1 / \Delta$ & . & rV. نشان دادن توجه به نيازهاى بيمار در حين صحبت كردن با وى \\
\hline
\end{tabular}

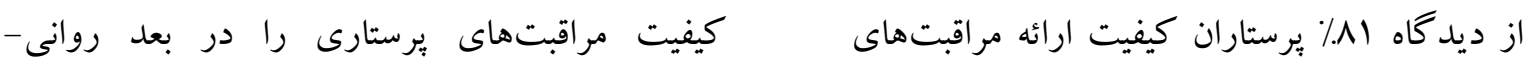

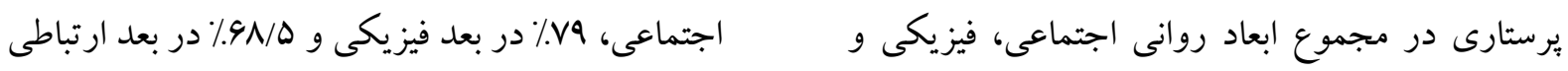

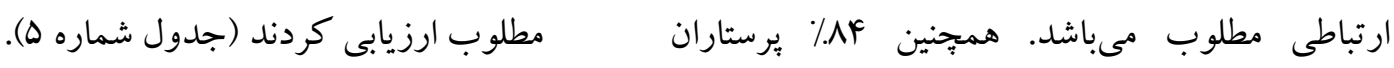

\begin{tabular}{|c|c|c|c|}
\hline \multicolumn{2}{|c|}{ يرستار } & \multirow{2}{*}{\multicolumn{2}{|c|}{ ابعاد }} \\
\hline درصد & تعداد & & \\
\hline 1 & r & ن نامطلوب & \multirow{3}{*}{ روانى - اجتماعى } \\
\hline 10 & $\mu$. & تا حدودى مطلوب & \\
\hline$\Lambda F$ & 191 & مطلوب & \\
\hline$r / \Delta$ & $\Delta$ & نامطلوب & \multirow{3}{*}{ فيزيكى } \\
\hline $1 N / \Delta$ & rV & تا حدودى مطلوب & \\
\hline Vq & 101 & مطلوب & \\
\hline$r$ & 4 & نامطلوب & \multirow{3}{*}{ ارتباطى } \\
\hline$r N / \Delta$ & $\Delta V$ & تا حدودى مطلوب & \\
\hline $91 / 0$ & IrV & مطلوب & \\
\hline$r$ & F & نامطلوب & \multirow{3}{*}{ كيفيت مراقبت يرستارى } \\
\hline IV & $\mu F$ & تا حدودى مطلوب & \\
\hline$\wedge 1$ & 194 & مطلوب & \\
\hline
\end{tabular}

مورد بررسى بر اساس آزمون من ويتنى بين وضعيت كيفيت مراقبت هاى برستارى و جنس ارتباط معنادارى

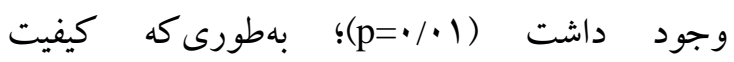
مراقبتهاى برستارى، برستاران زن بهتر از كيفيت مر اقبت هاى يرستارى يرستاران مرد ميىباشد.
بر اساس نتايج آزمونهاى آمارى بين وضعيت كيفيت مراقبتهاى برستارى با متغيرهاى جمعيت شناختى نظير سن، وضعيت تأهل، نوبت كارى، مدرك يرستارى، وضعيت استخدامى و سابقه خدمتى برستاران ارتباط معنادارى وجود نداشت. تنها از بين متغيرهاى 
مطالعه فوق همخوانى دارد. اين در حالى است كه يافتهاى مطالعه حقيقى خوشخو و همكاران نشان داد كه اكثر بيماران در ابعاد روانى اجتماعى و ارتباطى كيفيت مراقبت را نامطلوب كزارش كردند (IV) همجنين اكثريت بيماران مبتلا به ايدز در مطالعه دبيريان و همكاران كيفيت مراقبت برستارى در اين ابعاد را ضعيف ارزيابى كردند (·). در مطالعه دهقانى و و

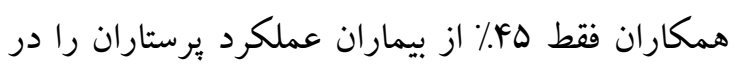
بعد ارتقاى كيفيت مراقبت از بيمار مطلوب ارزيابى كردند (Y\&). در مطالعه مظلوم به نقل از زمان زاده نيز در خصوص ديد گاه بيماران در مورد كيفيت مراقبتها، بيشترين نارضايتى مربوط به برآورده كردن نيازهاى

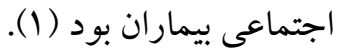

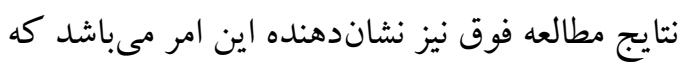
كيفيت مراقبت در ابعاد ارتباطى نسبت به ساير ابعاد مراقبتى ضعيفتر مىباشد. نتايج مطالعه جنجوينى نيز

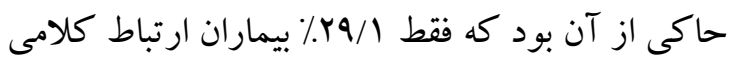

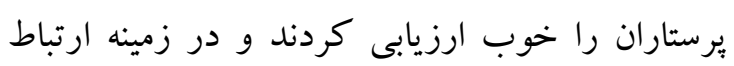

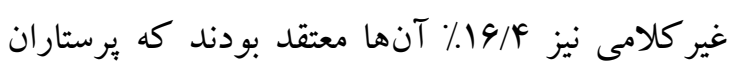
قادر به برقرارى ارتباط غير كلامى خوب هستند (YV). لذا از آنجا كه وظيفه يكك بِرستار در درجه اول

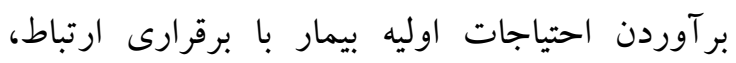
مداخله كردن در ابعاد مختلف روانى اجتماعى، جسمى و ارتباطى و همجينين كمكك و هميارى بيمار در امر درمان است. در صورتى كه برستار بتواند با بيمار ارتباط مناسبى برقرار نموده و به نيازهاى بيمار در تمام

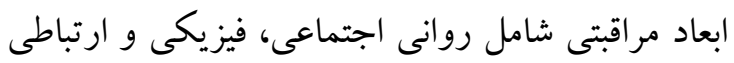

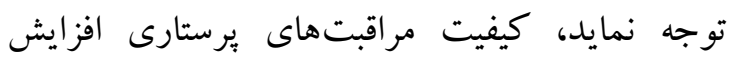
مىبايد و جنانجه مر اقبتهاى ارائه شده مناسب و دقيق باشند، بيماران نيز رضايت بيشترى خواهند داشت (YN).

\section{بحث و نتيجه كيرى}

نتايج اين مطالعه نشان داد كه كيفيت مراقبتهاى يرستارى از ديدكاه اكثريت يرستاران در هر سه بعد مراقبتى مطلوب مىباشد. در مطالعهاى كه پِارياد و و همكاران جهت بررسى ديدگاه سريرستاران در مورد كيفيت مراقبتهاى يرستارى در رشت انجام دادند نيز

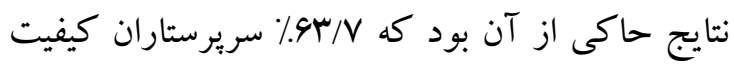

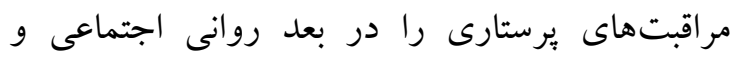

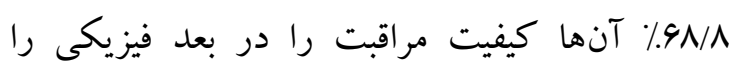
مطلوب ارزيابى كردند (YF). در مطالعه زمان زاده و همكاران نيز نتايج نشان داد اكثريت يرستاران كيفيت مراقبت را در سه بعد روانى اجتماعى، فيزيكى و ولته ارتباطى مطلوب و اكثريت بيماران آن را نامطلوب ارزيابى نمودند (1) كه با يافتهاى مطالعه فوق همخوانى دارد. در مطالعه Shannon و همكاران

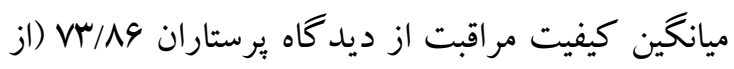
×. (1) بود (19). در مطالعه نيشابورى و همكاران نيز كيفيت مراقبتهاى بيرستارى از ديدكاه اكثريت يرستاران در هر دو بعد مراقبى روانى اجتماعى و ارتباطى مطلوب بود در حالى كه از ديدكاه اكثريت بيماران كيفيت مراقبتها در بعد روانى اجتماعى و ارتباطى تا حدودى مطلوب بود (ها). از جمله در

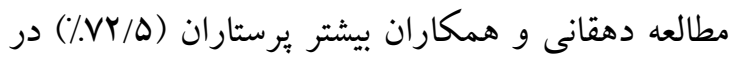
ابعاد مسئوليت يذيرى، ارتقاى كيفيت مر اقبت از بيمار و

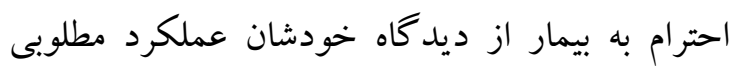
داشتند (YD). در مطالعه ابراهيمى و همكاران نيز از ديد گاه اكثر نمونههاى بثزوهش كيفيت مراقبت در بعد فيزيكى و ارتباطى در سطح مطلوب قرار داشتند (YY).

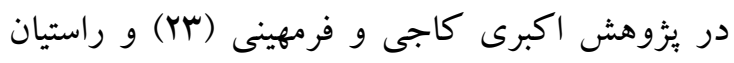
(Y) يرستاران مطلوب ارزيابى شده است كه با يافتهاى 
بررسى ارتباط بين وضعيت كيفيت مراقبتهاى يرستارى و متغيرهاى جمعيت شناختى برستاران نشان داد كه بين كيفيت مراقبتهاى برستارى در بين يرستاران مرد و زن (متغير جنس) رابطه معنادارى وجود دارد. به طورى كه كيفيت مراقبتهاى برستارى، يرستاران زن بهتر از كيفيت مراقبتهاى يرستارى يرستاران مرد مىباشد. در مطالعه دهقانى و همكاران نيز بين جنس و كيفيت عملكرد اخلاق حرفهاى بيرستاران در مجموع، سه بعد مسؤوليت يذيرى، ارتقاى كيفيت مراقبت از بيمار و احترام به بيمار رابطه معنادارى وجود داشت، بهطورى كه برستاران زن بيشتر از برستاران مرد اظهار كردند كه در بعد ارتقاى كيفيت مراقبت از بيمار و مجموع كيفيت عملكرد حرفهاى، معيارهاى حرفهاى را رعايت مى كنند (YD). همجِنين نتايج مطالعه سخنور و همكاران حاكى از آن بود كه بين جنس و به كار گيرى اصول اخلاقى توسط يرستاران رابطه معنادارى وجود دارد بهطورى كه عملكرد برستاران زن در ابعاد مراقتى يُى بهتر از يرستاران مرد مىباشد (MF) كه اين نتايج با بـان يافتهاى مطالعه فوق همخوانى دارد. يثزوهش انجام شده توسط مرير و همكاران نشان داد كه بين رعايت معيارهاى حرفهاى بالينى و متغيرهايى مانند سن و سابقه

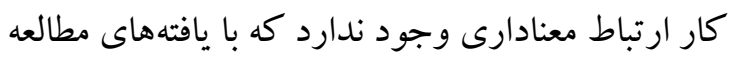
فوق همخوانى دارد، همجينين در مطالعه مرير و همكاران بين رعايت معيارهاى حرفهاى بالينى و جنس

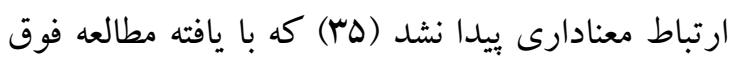
مطابقت ندارد. در مطالعه تفاق و همكاران نيز بين ميزان رعايت اخلاق حرفهاى و متغيرهايى همجون سن، جنسيت، بخش و سابقه كارى يرستاران ارتباط

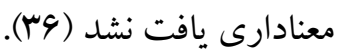
بين وضعيت كيفيت مراقبتهاى يرستارى با ساير متغيرهاى جمعيت شناختى نظير سن، وضعيت تأهل،

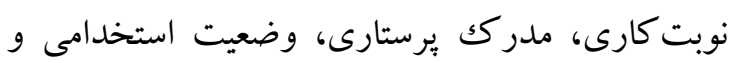

همجنين يافته هاى مطالعه فوق نشان داد كه كيفيت مر اقبتهاى برستارى در برخى جنبههاى مراقبتى روانى اجتماعى، فيزيكى و ارتباطى ماند معرفى بيماران جديد به بيمار، توجه به تقاضاى بيمار براى ديدن يك روحانى، توضيح در رابطه با اثرات درمانى، جانبى و هشداردهنده داروى مصرفى، آكاهى بيماران از نتايج آزمايشان و درمانها، معرفى منابع و سازمانهاى ارجاعى لازم جهت كمكك در امور مالى، ويشبينى نيازهاى بيماران، درك اضطراب خانو اده آنها و ارائه آموزشهاى لازم جهت كاهش اضطراب، تخصيص زمان كافى به بيمار و خانواده بيمار جهت مطرح كردن سؤالات خود و آموزش استراحت متناوب در بين فعاليت ها براى حفظ انرزى بايين مىباشد. نتايج مطالعه و و همكاران حاكى از آن بود كه تنها .r. Deccaache از بيمارانى كه در بيمارستان بسترى بودهاند اظهار نمودهاند كه اطلاعات كافى و مشاوره در زمينه شرايط سلامتى و داروهاى مصرفى خود دريافت نمودهاند (Y9). نتايج مطالعه مظاهرى و محمدى نشان داد كه آموزشهاى كافى در ابعاد مختلف مورد نياز به بيماران داده نمى شود (·r). در مطالعه قورجيانى و همكاران

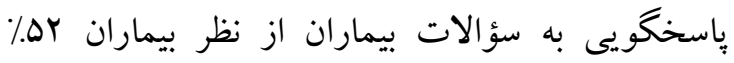
رعايت شده است (اس). در مطالعه بابا محمودى ياسخكويى گروه درمانى به سؤالات بيمار و خانواده

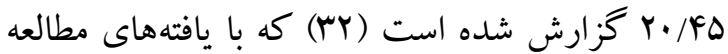
فوق همخوانى دارد. در كل Gunther \& Alligood معتقد هستند كه يرستاران هم از نظر قانونى و هم از نظر اخلاقى نسبت به كيفيت مراقبتى كه ارائه مىدهند داراى مسئوليت و تعهد مىباشند و بايد بدانند كه هم جنبههاى روانى - اجتماعى مراقبتى كه ارائه مىنمايند و هم تخصص و مهارت آنها در امر ارائه مراقبت هر دو در دركك بيمار نسبت به كيفيت مراقبت تأثير دارد 


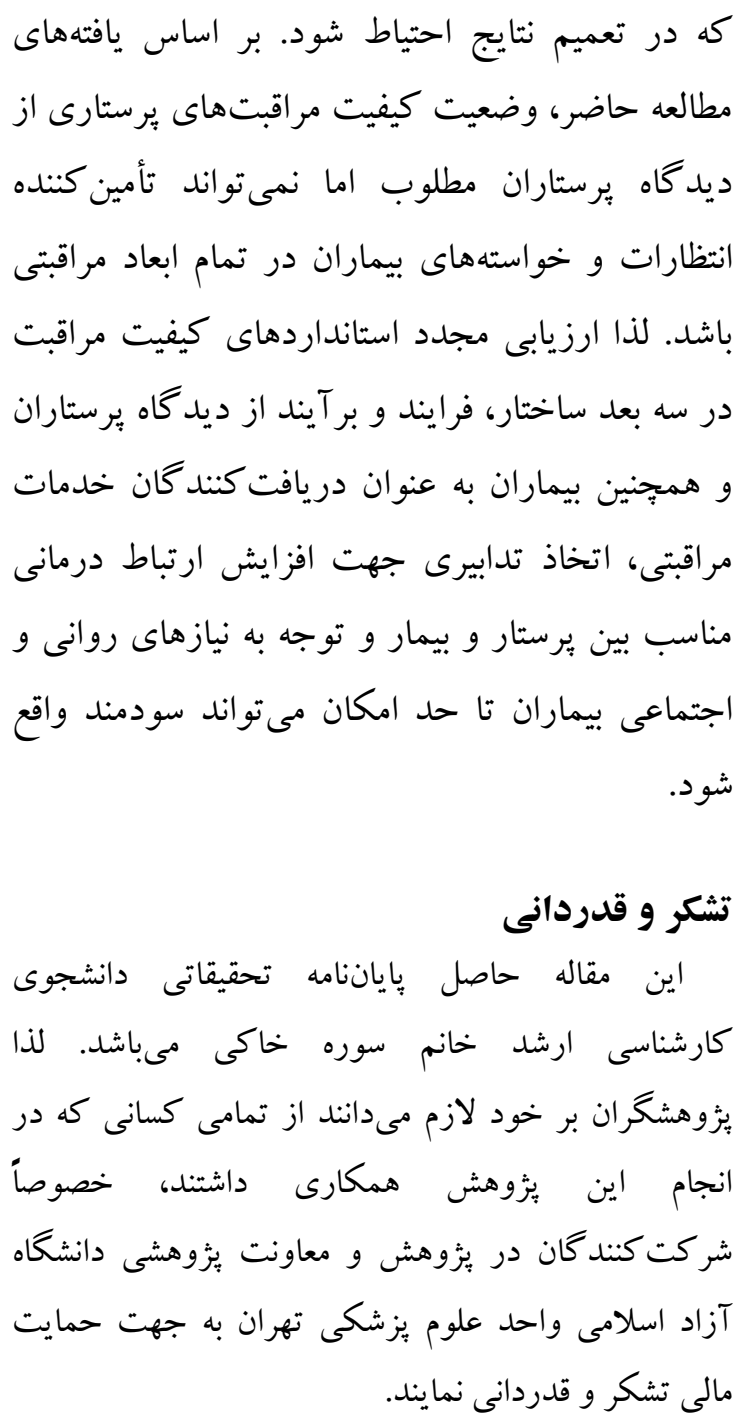

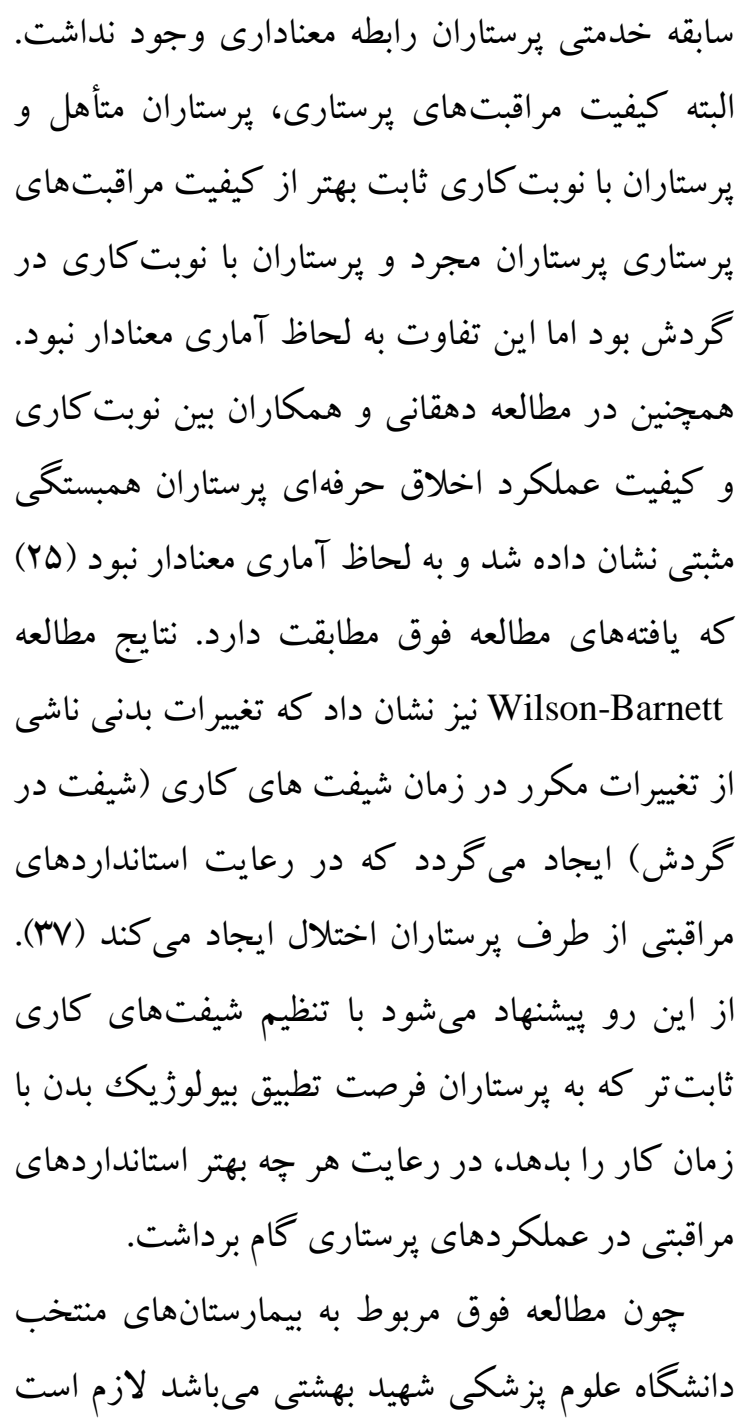

\section{Reference}

1. Zamanzadeh V, Moghadasian S, Valizadeh L, Haghighi Khoshkho N. Compare of nurses and patient perspective about the quality of nursing care provided in educational hospitals in Tabriz. Journal of Caring Sciences 2006; 2: $4-12$.

2. Navulur Rb. Integrated quality improvement program in patient care. Nursing \& Health Science 1999; 1(4): 249-256.

3. Ahmadi F, Nobahar M, Alhani F, Falahi Khoshknab M. Perspectives of retired nurses on factors that affect quality of nursing care.Hayat 2011; 17(1): 24-34.

4. Marquis BL, Huston CJ. Leadership roles and management functions in nursing: Theory and application. Lippincott Williams \& Wilkins. 2009.

5. Foley ME. Nurses: assuring quality care for all populations. Leonard Davis Institute of health economics, university of Pennsylvania, American Nurses Association. 2001.

6. Zaeimi Pour Kermanshahi M, Vanaki Z, Haji Zadeh E. The effect of manager nurses' management skills retraining on empowerment of nursing staff. Journal of Zanjan University of Medical Sciences \& Health Services 2005; 13(50): 14-21.

7. Brundtland GH. Strategic directions for strengthening nursing and midwifery services. Geneva: World Health Organization; 2002. 
8. Pazargadi M. Zaghari M. Abedi Z. Quality of nursing care of nurses view: a quality study. Journal of Shahid Beheshti University 2007; 31(2): 147-153. [Persian].

9. Chow F L W, Suen L K P. Clinical staff as mentors in pre-registration undergraduate nursing education: students perceptions of the mentors roles and responsibilities. Journal of Nurse Education Today. 2001; 21: 350-358.

10. Williams AM. The delivery of quality nursing care: a grounded theory study of the nurse's perspective. J Adv Nurs. 1998 Apr; 27(4): 808-16.

11. Swansburg RC, Swansburg RJ. Introductory management and leadership for nurse. 2nd ed. Sudbury: Jones \& Bartlett Publishers; 1999.

12. Ovretveit J. Quality evaluation and indicator comparison in health care. International Journal of

Health Planning and Management 2004; 16(3): 229-241.

13. Brooten D, Youngblut JM, Kutcher J, Bobo C. Quality and the nursing workforce: APNs, patient outcomes and health care costs. Nursing outlook 2004; 52(1): 45-52.

14. Mohajjel Aghdam A, Hassankhani H, Zamanzadeh H, Khameneh S, Moghaddam S.Nurses' Performance on Iranian Nursing Code of Ethics from Patients' Perspective. Iran Journal of Nursing 2013; 26 (84):1 - 11.[Persian]

15. Neishabory M, Raeisdana N, Ghorbani R, Sadeghi T. Nurses' and patients' viewpoints regarding quality of nursing care in the teaching hospitals of Semnan University of Medical Sciences, 2009. Koomesh 2010; 12(2): 134-143.

16. Shannon SE, Mitchell PH. Cian KC. Patients, Nurses, and physicians have differing views of quality of critical care. Journal of Nursing Scholarship 2002; 34: 173-179.

17. Haghighi Khoshkho N. The quality of nursing care from nurses and patients viewpoints in the Teaching hospitals of Tabriz university of Medical Sciences. [MA thesis]. Tabriz: Tabriz University of Medical Sciences; 2004.

18. Jafari manesh H, Ranjbaran M, Vakilian K, Tajik R, Almasi-Hashiani A. Nursing's code of ethics: a survey of respecting the code among nursing students. Iranian journal of medical ethics and history of medicine 2014; 6 (6): 45-55.

19. Redfern SJ, Norman IJ, Tomalin D, Oliver S. Assessing quality of nursing care. Quality in Health Care 1993; 2(2): 124.

20. Dabirian A, Zolfaghari H, Saidi ZA, Alavi-Majd H. Views of AIDS patients regarding nursing care quality in healthcare centers affiliated to Shaheed Beheshti and Tehran Universities of Medical Sciences. Journal of Shahid Beheshti School of Nursing \& Midwifery 2008; 18(61): $40-45$.

21. Rastian ML. The effect of nursing process applying on nursing care quality of patients in Shahid Beheshti hospital of Yasouj university of Medical Sciences [MA thesis]. Yasouj: Yasouj University of Medical Sciences; 2012.

22. Ebrahimi H, Namdar H, Vahidi.Quality of nursing care in psychiatric wards of university hospitals in northwest of iran from the perceptions of nurses. Journal of Caring Sciences (JCS) 2012; 1(2): 79-84.

23. Akbari Kaji M, Farmahani Farahani B. the effect of nursing process education on nursing care quality of schizophrenic patients. Journal of Kashan University of Medical Sciences (FEYZ) 2011; 15(1): 32-37.

24. Paryad A, Masooleshadman R, Kazemnejad A. Evaluating of head nurses perspectives in quality of care in healthcare centers in Rasht. Holistic Nursing and Midwifery Journal 2001; $10(36-37): 30$ - 38.

25. Dehghani A. Kermanshahi SM. Evaluating of compliance with professional ethical standards in nursing practice from Nursing Staff's Viewpoints in in Tehran University of Medical Sciences. Modern care journal 2013; 9 (3): 208-216. 
26. Dehghani A, Ordoubadi N, Shamsizadeh M, Parviniyan Nasab A, Talebi M. Perspective of patients about compliance with standards of professional ethics in nursing practice. Journal of Nursing Education2014; 3 (2): 76-84.

27. Panjvini S. Evaluation of nursing staff communicates with patients in public wards of educational hospitals in Sanandaj city. Journal of School of Nursing and Midwifery 2002; 1(2): $1-8$.

28. Parsa-Yekta Z, Sharifi-Neiestanak N, Mehran A, Imani-Pour M. Quasi experimental research on anxiety and satisfaction of patients undergoing open cardiac surgery having intubation. Hayat 2002; 8(3): 5-12.

29. Deccache A, Aujoulat I. A European perspective: common developments, differences and challenges in patient education. Patient Educ Couns. 2001; 44(1): 7-14.

30. Mazaheri E, Mohammadi MA. [Review status and barriers of patient education of perspective of personal and students of Ardabil University of Medical Sciences report research plan of unit management and information of Ardabil University of medical sciences], 2004. [Persian] [cited 2014 May 29] available from: http://eprints.arums.ac.ir/381/ 31. Ghurchiani F. Barati Martati A. Abolghasem Gorji H. Khatami FiroozabadiAM. Haghani H. Goldoost Marandi F. Ritual observance of ethicsand patient care nurses in teaching hospitals of Tehran University of MedicalSciences.Medical Ethics 2013;7(23): 6379.[Persian]

32. Babamahmoodi F, Meftahi M, Khademloo M, Hesamzadeh A. Observation of patient's right charter in Mazandaran teaching hospitals: patients view. Iranian Journal of Medical Ethics and History of Medicine 2011; 4(4): 37-44.

33. Gunther M, Alligood MR. (2002). A discipline specific determination of high quality nursing care. Journal of Advanced Nursing, 38(4), 353-359.

34. Sokhanvar R. The effect knowledge of nursing ethics in clinical decision-makings and applying the perspective of working nurses in Shiraz University of Medical Sciences. [MS Dissertation] Shiraz: Shiraz University of Medical

Sciences, Faculty of Nursing \& Midwifery; 1997. [Persian]

35. Meurier C, Vincent C, Parmar D. Learning from errors in nursing practice. J Adv Nurs 1997; 26(1):111-9

36. Tefaq M R, Nikbakht Nasrabadi A, Mehran A, Din Mohammad N. Evaluation of professional ethics in the implementation of drug orders by nurses. $J$ Nurs and Midwifery.Tehran University of Medical Sciences1383: 10 (4): 77-86. [persian]

37. Wilson-Barnett J. Ethical dilemmas in nursing. J Med ethics. 1986; 12(3): 123-135. 